\title{
Adrenal suppression in an asthmatic presenting after change from high dose inhaled fluticasone propionate to inhaled budesonide
}

\author{
Zainab B Abdurahman ${ }^{1 *}$, Douglas P Mack ${ }^{2}$ \\ From Canadian Society of Allergy and Clinical Immunology Annual Scientific Meeting 2010 \\ Victoria, Canada. 3-6 November 2010
}

\begin{abstract}
Introduction
Adrenal suppression with high doses of inhaled corticosteroids has been reported in the literature with suggestion of fluticasone propionate (FP) being a more potent adrenal suppressant than budesonide (BUD). To our knowledge, we present the first case of adrenal suppression after change from high dose FP to BUD therapy.
\end{abstract}

\section{Case description}

A ten-year-old boy with asthma, peanut allergy, and allergic rhinitis had been maintained on a regimen of $\mathrm{FP} /$ salmeterol $500 \mathrm{mcg}$ per day and mometasone furoate nasal spray $50 \mathrm{mcg}$ per day. During exacerbations FP $500 \mathrm{mcg}$ per day was added. He had no oral steroid usage. After a stable period with only $\mathrm{FP} /$ salmeterol, his regimen was changed to $\mathrm{BUD} /$ formoterol $800 \mathrm{mcg}$ per day. Shortly after this change in regimen, he began to experience spells of dizziness, fatigue, nausea and diaphoresis with exercise. A random glucose was low at 3.4 $\mathrm{mol} / \mathrm{L}$ and an $\mathrm{AM}$ cortisol was low at $67 \mathrm{nmol} / \mathrm{L}$. With endocrinologist recommendation adrenal suppression was diagnosed, hydrocortisone therapy at $18 \mathrm{mg} / \mathrm{m}^{2}$ and ciclesonide were initiated. He is currently stable, tapering hydrocortisone therapy, with plans for ACTH stimulation test when hydrocortisone is discontinued.

\section{Discussion}

A number of studies have suggested that the systemic bioavailability and potential for adrenal suppression is increased with FP compared to BUD. It is our suspicion that his underlying adrenal suppression was revealed

\footnotetext{
* Correspondence: zainab.abdurrahman@medportal.ca

'Dept of Clinical Immunology and Allergy, McMaster University, Hamilton, ON, Canada

Full list of author information is available at the end of the article
}

presenting as withdrawal after switching to a less bioavailable steroid. Adrenal suppression is an important consideration for physicians tapering patients from chronic high dose fluticasone therapy to less bioavailable inhaled corticosteroids.

\section{Author details \\ ${ }^{1}$ Dept of Clinical Immunology and Allergy, McMaster University, Hamilton, ON, Canada. ${ }^{2}$ Dept of Pediatrics, McMaster University, Hamilton, ON, Canada.}

Published: 4 November 2010

doi:10.1186/1710-1492-6-S2-P27

Cite this article as: Abdurahman and Mack: Adrenal suppression in an asthmatic presenting after change from high dose inhaled fluticasone propionate to inhaled budesonide. Allergy, Asthma \& Clinical Immunology 2010 6(Suppl 2):P27.
Submit your next manuscript to BioMed Central and take full advantage of:

- Convenient online submission

- Thorough peer review

- No space constraints or color figure charges

- Immediate publication on acceptance

- Inclusion in PubMed, CAS, Scopus and Google Scholar

- Research which is freely available for redistribution
() Biomed Central 